\title{
The Comfort of Post Orthopedic Surgery's Client Given Murottal Al-Qur'an
}

\author{
Anggia Astuti \\ Master of Nursing Students, Faculty of Nursing \\ Universitas Airlangga \\ Surabaya, Indonesia \\ E-mail: Anggi_oi26@yahoo.com
}

\author{
Nursalam \\ Basic, Medical Surgical and Critical Nursing Departement \\ Faculty of Nursing, Universitas Airlangga \\ Surabaya, Indonesia \\ Laily Hidayati \\ Basic, Medical Surgical and Critical Nursing Departement \\ Faculty of Nursing, Universitas Airlangga \\ Surabaya, Indonesia
}

\begin{abstract}
Introduction: Surgery form of orthopedic surgery is a stressor for those clients who can evoke a stress reaction both physiologically and psychologically. Physiological responses can be painful, while the response can be either psychological anxiety is a disorder in which both comfort. This study used a qualitative descriptive design, aims to describe the perceived experience post-surgical orthopedic clients were given murottal Al-Qur 'an on comfort. The number of participants in this study were obtained 8 participants. Participants were given murottal AlQur'an Al-Fatiha, Al-Ikhlas, Al-Falaq and An-Naas with Qari 'Muhammad Junaid Thoha using the speaker box for 20 minutes done twice within 24 hours post-surgery orthopedi. Three themes as a result of research based on the theory of comfort Kolcaba, namely the need for comfort care, nursing interventions for comfort and comfort after nursing actions (murottal Al-Qur'an). Listen to murottal Al-Qur 'an, read tartil and correct manner, will bring tranquility of soul.
\end{abstract}

Keywords- murrottal Al-Qur'an, post-surgical orthopedic, comfort

\section{INTRODUCTION}

Orthopedic Surgery is a surgical procedure to restore musculoskeletal dysfunction conditions such as unstable fracture, deformity, joint dislocation, tissue necrosis and infection, compartment syndrome, and musculoskeletal system [1]. A national health survey noted that the fracture in 2008 that is $27.7 \%$ and in 2009 increased to $54.5 \%$, the incidence of fractures require treatment of serious action to prevent the occurrence of unwanted things [2]. Surgery is a stressor for those clients who can evoke a stress reaction [3], [4].

During the recovery period after surgery, the client will feel the helplessness and loss of control, physical discomfort and anxiety about the development of health. Plus unfamiliar environments can create physical complications and extension of the healing process [5].

Comfort as a state has been the fulfillment of basic human needs that is individualized and holistic [6]. With the fulfillment of comfort can cause feelings of peace on the individual self. Convenience theoretical approach developed by Kolcaba offer comfort as the forefront of the nursing process. Kolcaba holistic view that comfort is the comfort that includes a thorough physical comfort, psychospiritual, environmental, and social. The level of comfort divided into three relief where clients require specific needs of comfort, ease that is free from a sense of discomfort and transcendence that is able to tolerate or adapt to discomfort [7], [8].

Management of postoperative administration of drugs is not only timely, but how a nurse can create a sense of comfort for the client in a long time. Interventions made by Kolcaba (2005) aims to improve the sense of comfort that is divided into three categories, the first of maintaining homeostasis and pain control, provide training both relieve pain and anxiety, all three with soothing to the soul so that clients feel cared for. Leisure has become the primary goal of nursing, because the healing comfort can be obtained [8]. Interventions to feeling comfortable is nursing actions and aimed to achieve the convenience needs of care recipients, including physiological, social, cultural, economic, psychological, spiritual, environmental, and physical intervention [7].

Holistic intervention that can be done to create a sense of comfort such as deep breathing, guided imagery, progressive muscle relaxation, music therapy and art (recitation of the Quran tartil accordance with the recitation). Murottal Qur'an is one of the music that has a positive effect for the listener [9]. Murrotal a sound recording of the Qur'an were sung by a qori '(readers of the Qur'an) [10]. Chant the Qur'an physically contain elements of the human voice, the human voice is an instrument of the amazing healing and tools that are easiest to reach.

Murottal therapy is the treatment of reading verses of the Qur'an that when recited will give a positive response to the person's body [11], while according [12] murrottal is sound or chant verses -Qur'an which when played can lower stress hormones, activate natural endorphins, increase the feeling of relaxation, and shifted from fear, reduce pain, anxiety and tension, improve chemical systems, and hemodynamic body that lowers blood pressure and slows respiration, heart rate, pulse rate, and brain wave activity that will cause a sense of comfort [13]. 


\section{METHOD}

Study uses descriptive qualitative design aimed to describe the perceived experience post-surgical orthopedic clients were given auditory stimuli murottal Qur'an to comfort. The number of participants depends on the number of participants recommended by Riemen is 3-10 participants (Creswell, 1998). By purposive sampling, participants were selected according to the inclusion criteria, namely: Islamic religion, age 20-35 years, understand reading the Qur'an, composmentis and speak Indonesian. Data was collected by interview. Participants were given auditory stimuli murottal Al-Qur'an Al-Fatiha, Al-Ikhlas, Al-Falaq and An-Naas with Qari 'Muhammad Junaid Thoha using the speaker box brands SONIA BE 2001 for 20 minutes done twice within 24 hours post-surgery orthopedics.

\section{RESUlt}

Participants in this study is 8 client after orthopedic surgery, with an age range of 20-35 years, four men and four women, only this time undergoing orthopedic surgery, Javanese and Madurese, junior high school education up to college, work factory workers, peasants, housewives, teachers and students.

Having analyzed the data obtained four themes as a result of research based on the theory of comfort Kolcaba, namely the need for comfort care, nursing interventions for comfort, intervening variables and comfort after nursing actions (murottal Qur'an).

\section{Theme 1: comfort care needs}

Scene comfort care needs identified through subtema comfort needs and perceptions about comfort. Subtheme comfort needs derived from the statement:

$$
\begin{aligned}
& \text { "... Not comfort miss, post accident, illness continues } \\
& \text { surgery are double pain"(P7) } \\
& \text { "... sick, the pain because post accident and post surgery, } \\
& \text { can not move, tired, fear of movement" (PI) } \\
& \text { "... when the effect of medicine gone, my legs really hurt" } \\
& \text { (P3) } \\
& \text { "... pain, but I hold" (P4) } \\
& \text { "... cannot sleep, frequently woke up, want go home soon" } \\
& (P 1)
\end{aligned}
$$

Subtheme perception of comfort derived from the statement:

$$
\begin{aligned}
& \text { "... .comfort is not feel pain, able to sleep"(P7) } \\
& \text { "... when no pain anymore and sleep nicely maybe its } \\
& \text { comfortable" (PI) } \\
& \text { "... I know Iam sick, but how can I hold it"(P3) } \\
& \text { "... . when I ignore the painfull I caleed it comfort, maybe I } \\
& \text { can reach it at home" (P5) }
\end{aligned}
$$

\section{Theme 2: nursing interventions for comfort}

The theme for the convenience of nursing intervention is interpreted as an act designed to meet the comfort needs of participants. More emphasis placed on participants' perceptions of nursing interventions that are taught and offered to participants to meet this comfort, by the statement:

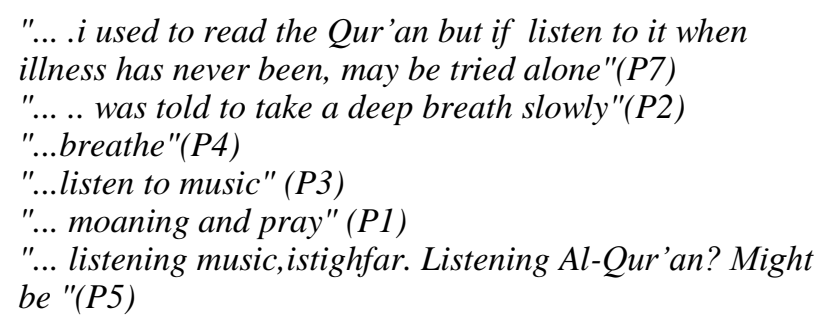

\section{Theme 3: Comfort after the nursing actions (murottal Qur'an)}

Comfort theme post nursing actions (murottal Qur'an) as an expression conveyed diitepretasikan participants on experiences during auditory stimuli murottal given the Qur'an against comfort. Obtained a statement of this theme:

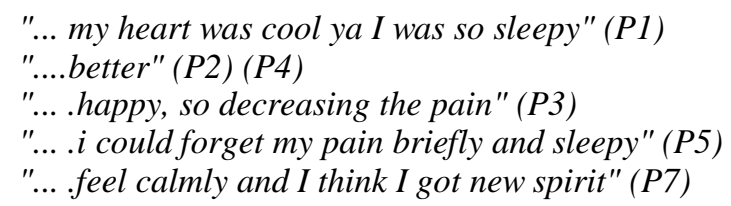

\section{DISCUSSION}

Health care needs (need for health services) is defined as a need for comfort. From the results, the majority of participants expressing discomfort after orthopedic surgery. Postoperative pain is a component that is not pleasant and can cause anxiety inevitable from the post-operation. The sensation of pain began to be felt before the full back client awareness and increasing with the decreasing influence of anesthesia. During the recovery period after surgery, the client will feel the helplessness and loss of control, physical discomfort and anxiety about the development of health. Plus unfamiliar environments can create physical complications and extension of the healing process [5]. According ([14]), this can occur because of two pain stains that is the tissue incision surgery as well as the trauma of the broken bone itself.

The nursing intervention is defined as an action that is designed to meet the needs of comfort.According to the results, the majority of participants have a good perception of action designed specifically to meet the comfort, it obtained other than nursing interventions as well as from habit participants to manage stress. Therapy for psychological comfort include massages, environmental adaptation that enhances peace and tranquility, guided imagery, music therapy, recalls, etc. [6].

Comfort after the nursing actions (murottal Qur'an) as an expression conveyed interpreted by participants on experiences during auditory stimuli murottal given the Qur'an against comfort. From the results, the majority of participants gave positive responses after listening murottal Qur'aan. This indicates that the participants feel comfortable.

Murottal is a sound recording of the Qur'an were sung by a qori '(readers of the Qur'an) [10]. Listen to the verses of the Qur'an are recited in tartil and correctly, will bring peace of mind. Reflexion contain human elements which are the instruments of healing and tools that are easiest to reach. 
Sounds can lower stress hormones, activate natural endorphins, increases feelings of relaxation, improve the system of body chemistry that lowers blood pressure and slows respiration, heart rate, pulse rate, and brain wave activity [15].

Having spoken we read the Quran or listen to the recitation of the Qur'an impulses or stimuli will sound received by the ear readers, then start the process of listening ears. Physiology of hearing is a process in which the ear receives sound waves, frequency and send information to distinguish the central nervous system [16].

Sound vibrations reading the Qur'an will be caught by the ear to be routed to the ear canal and the tympanic membrane (membrane in the ear) so as to make vibrate. This vibration is passed to the ossicles are linked with one another. Physical stimuli was changed by the differences of potassium ions and sodium ions into the flow of electricity through the nerves N.VIII (Vestibule Cokhlearis) to the brain rather diarea hearing. This area is responsible for analyzing the complex sound short-term memory, the comparison tone, inhibiting the desired motor response, a serious hearing and so on [17].

From the secondary auditory areas (auditory interpretation area) reading the Qur'an signal is passed goto posterotemporalis temporal lobe of the brain known as Wernicke area. In this area the signal from somatic association areas, visual, and auditory meet each other. This area is often referred to by various names stating that this area has the benefit of a thorough, public interpretation area, the area of diagnostics, knowledge areas, and tertiary association areas [16]. Wernicke's area is the area of interpretation (interpreting or give the impression of) language and is closely related to the primary auditory area of the secondary. This close relationship may be due to the events that preceded the introduction of language by hearing [16].

After being processed in the Wernicke area through the bundle that connects the prefrontal association area (meaning events) signals in the area of Wernicke sent to the prefrontal association area. Meanwhile beside delivered to cortical auditory primary of the thalamus, also delivered to the amygdala (where the emotional memory) which is an important part of the limbic system (the system that affect emotions and behavior), as well as receive signals from the thalamus (one part of the brain responsible for receiving forwarded messages from the senses gets another brain). The amygdala also receives signals from all parts of the limbic cortex (emotion / behavior) as well neocortical temporal lobe (cortex or cerebral cortex that exist only on manusis), parietal (part of the midbrain) and occipital (back of the brain), especially diarea association auditory and association areas visual [16].

The thalamus also run the signal to the neocortex (brain area that serves to think or process data as well as information coming keotak). In the neocortex signal organized into objects that were understood and sorted according to their meaning, so that the brain recognizes each object and sense its presence. Then run the signal to the hippocampus amygdala. The hippocampus is essential for helping the brain to store new memories. This is possible because the hippocampus is one of the many important exit point from the area of "reward" and "punishment". Among the motivations that there is a boost in the brain to remember the experiences, thoughts are pleasant, and unpleasant. However read the Quran without knowing their meaning remains also helpful if readers with sincerity and humility. Because the Qur'an will give a positive impression on the hippocampus and amygdala, giving rise to a positive mood [16].

The theory of comfort as a middle range theory because it has a low level of abstraction and easily applied in nursing practice. Kolcaba assess comfort by creating a taxonomy structure which is based on three types namely reliefe comfort, ease, and transcendence. Kolcaba linking the three types of comfort with the convenience of four contexts: physical, psychospiritual, environmental, and social [7].

Comfort care is a philosophy of health care that is convenient for the client. Comfort care has three components, namely the appropriate intervention and timely, models of care attention and empathy, focus on patient comfort. Comfort measures are interventions which are designed to improve the comfort of the client or family. Comfort needs is the need for comfort relief, ease, and transcendence in the context of human experience physical, psychospiritual, sociocultural and environmental. Intervening variables are positive and negative factors that little can be controlled by a nurse or institutions but directly influence the success of an intervention plan comfort. Examples of intervening variabels is social support, poverty, prognosis, medical or psychological condition, and habits / patterns of health [7][18].

\section{CONCLUSSION}

The results of this study indicate post-surgical orthopedic clients experiencing discomfort associated with the condition post-surgery and post-trauma. Several independent nursing actions that received the client to reduce discomfort such as deep breathing and listening to music. Having given auditory stimuli murottal Qur'an clients feel calm and comfortable.

\section{REFERENCES}

[1] B. G. Smeltzer, Suzanne C \& Bare, Buku Ajar Keperawatan Medikal Bedah Brunner \& Suddarth. Jakarta: EGC, 2005.

[2] Kumagai, Medical Surgical Nursing, Concept and Practice, 2nd ed. Missouri: Saunders Elsevier, 2013.

[3] J. P. Desborough, "The stress response to trauma and surgery," Br. J. Anaesth., vol. 85, no. 1, pp. 109-117, Jul. 2000.

[4] S. Leardi, R. Pietroletti, G. Angeloni, S. Necozione, G. Ranalletta, and B. Del Gusto, "Randomized clinical trial examining the effect of music therapy in stress response to day surgery," Br. J. Surg., vol. 94, no. 8, pp. 943-947, Aug. 2007.

[5] T. L. et al Cutshall, Susanne M; Anderson, Patricia G; Prinsen, Sharon K; Wentworth, Laura J; Olney, "Effect of the Combination of Music and Nature Sounds on Pain and Anxiety in Cardiac Surgical Patients: A Randomized Study," Altern. Ther., vol. 17, 
no. 4, pp. 16-23, 2011.

[6] K. . D. M. M. A. Kolcaba, "Comfort Theory and Its Application to Pediatric Nursing," Pediatr. Nurs., vol. 31, no. 3, pp. 187-194, 2005.

[7] M. A. Kolcaba, K., \&DiMarco, "Comfort Theory and its application to pediatric nursing," Pediatr. Nurs., vol. 31, no. 3, pp. 187-194, 2005.

[8] A. . Alligood, M.R \&Tomey, Nursing Theorist And Their Work, 7th edition. USA: Mosby Inc, 2009.

[9] Widayarti, "Pengaruh Bacaan Al-Qur'an Terhadap Intensitas Kecemasan Pasien Sindroma Koroner Akut Di RS Hasan Sadikin," Universitas Padjajaran, 2011.

[10] Siswantinah, "Pengaruh Terapi Murrotal Terhadap Kecemasan Klien gagal Ginjal Kronik yang Dilakukan Tindakan Hemodialisa di RSUD Kraton Kabupaten Pekalongan.," Universitas Muhammadiyah Semarang, 2011.

[11] Gusmiran, Ruqyah Terapi Religi Sesuai Sunnah
Rosulullah SAW. Jakarta: Pustaka Marwa, 2005.

[12] Sa'dulloh, Sembilan Cara Cepat Menghafal AlQur'an. Jakarta: Gema Insani, 2008.

[13] C. J. Lysne and A. B. Wachholtz, "Pain, Spirituality, and Meaning Making: What Can We Learn from the Literature?," Religions, vol. 2, no. 1, pp. 1-16, Dec. 2010.

[14] Departemen Kesehatan, Buku Panduan Pelaksanaan Clinical Pathway. Jakarta: Depkes, 2014.

[15] Heru, Ruqyah Syar'I Berdasarkan Kearifan Lokal. Jakarta: PT Dian Rakyat, 2008.

[16] M. Pedak, Metode Supernol Menaklukkan Stres. Jakarta: Hikmah Publishing House, 2009.

[17] L. Sherwood, Fisiologi Manusia: Dari Sel ke Sistem Ed. 6. Jakarta: EGC, 2012.

[18] S. Peterson, S, J., Bredow, T, Middle Range Theories Application to Nursing Research. Philadelpia: Lippincot William \& Wilkins., 2004 